\title{
Spatial structure of the Caribbean lobster (Metanephrops binghami) in the Colombian Caribbean Sea
}

\author{
Jorge Paramo · Ulrich Saint-Paul
}

Received: 12 October 2010/Revised: 10 January 2011/Accepted: 17 January 2011/Published online: 30 January 2011

(C) Springer-Verlag and AWI 2011

\begin{abstract}
Crustaceans of the genus Metanephrops are of great commercial value in some tropical and subtropical regions. With the potential development of a new deep lobster fishery in the Colombian Caribbean Sea, the objective of this work is to describe for first time the patterns of spatial and bathymetric distribution, and diel migratory periodicity of the Caribbean lobster (M. binghami). Data were collected by trawling in depths between 200 and $550 \mathrm{~m}$ (100 m strata intervals) in the Colombian Caribbean Sea. Higher biomass and size of these crustaceans were found between 250 and $350 \mathrm{~m}$, with a maximum at about $300 \mathrm{~m}$. The study offers diel patterns of $M$. binghami, which suggests nocturnal activity and burrowing during daylight hours.
\end{abstract}

Keywords Colombian Caribbean · Deep-sea Caribbean lobster $\cdot$ Diel periodicity $\cdot$ Abundance

Communicated by H.-D. Franke.

J. Paramo $(\varangle)$. U. Saint-Paul

Leibniz-Zentrum für Marine Tropenökologie (ZMT),

Universität Bremen, Fahrenheitstr. 6, 28359 Bremen, Germany

e-mail: jorge.paramo@zmt-bremen.de;

jparamo@unimagdalena.edu.co

U. Saint-Paul

e-mail: ulrich.saint-paul@zmt-bremen.de

\section{J. Paramo}

Grupo de Investigación Ciencia y Tecnología Pesquera Tropical (CITEPT), Universidad del Magdalena, Cra. 32 No. 22-08

Avenida del Ferrocarril, Santa Marta, Colombia

\section{Introduction}

Species of the genus Metanephrops (Decapoda, Nephropidae) are dwellers of the outer continental shelf and continental slope (Tshudy et al. 2007) and are divided into four morphologic groups: arafurensis, binghami, japonicus and thomsoni (Tshudy et al. 2007; Chan et al. 2009). The binghami group is the only one distributed throughout the western Atlantic and is also known from southern high latitudes (Tshudy et al. 2007; Chan et al. 2009). This group contain only two species: the Caribbean lobster (Metanephrops binghami Boone 1927) and the Urugavian lobster (Metanephrops rubellus Moreira 1903). M. binghami is distributed from the Bahamas and southern Florida to French Guiana including the Gulf of Mexico and the Caribbean Sea (Holthuis 1991; Tavares 2002). Crustaceans of the genus Metanephrops are an important economic resource (Holthuis 1991; Chan 1998; Chan et al. 2009) in some tropical and subtropical regions. Three deep-sea crustaceans of the species Metanephrops are exploited commercially on the continental slopes of north-west Australia: M. boschmai (Holthuis 1964), M. andamanicus (Wood-Mason 1891) and M. australiensis (Bruce 1966; Ward and Davis 1987; Wassenberg and Hill 1989). New Zealand has developed a deep-sea lobster fishery, targeting scampi (M. challenger Balss 1914; Smith 1999). An economically important commercial fishery exists in Taiwan and East China Sea for M. thomsoni (Bate 1888), M.japonicus (Tapparone Canefri 1873) and M. formosanus (Chan and Yu 1987; Choi et al. 2008). M. binghami has potential for an economic exploitation in waters of Venezuela (Gómez et al. 2000; Gómez et al. 2005). Due to the substantial potential new fishery in the Colombian Caribbean Sea, the objective of this work is to describe for first time the patterns of spatial and bathymetric distribution of abundance and the diel periodicity of the Caribbean lobster (M. binghami). 


\section{Materials and methods}

Samples were collected in the Colombian Caribbean Sea by trawling in water depths between 200 and $550 \mathrm{~m}$ (100 $\mathrm{m}$ depth strata sampled at $24 \mathrm{~h}$ intervals). Two experimental trawl surveys were carried out in November 2009 (south zone) and in December 2009 (north zone; Fig. 1). The sample period corresponds to the dry season when the high-pressure system forces strong and constant westward trade winds, and the northern zone is affected by the Caribbean current and the upwelling of deep waters (Paramo et al. 2003). Samples were collected by the commercial shrimp trawler "Tee Claude" using a trawl with a cod-end mesh size of $44.5 \mathrm{~mm}$ from knot to knot, on a grid of 87 stations, with at least two hauls per $100 \mathrm{~m}$ depth stratum. We were unable to collect samples between Cartagena and the Magdalena River because of irregular depths. Appropriate trawl locations were identified using a commercial echosounder FURUNO FCV 1150 with a transducer frequency of $28 \mathrm{kHz}$. The haul duration was $30 \mathrm{~min}$, and the distance travelled by the net was estimated by means of a GPS Garmin MAP 76CSx. The swept area was estimated from the spread of the net $(11.58 \mathrm{~m})$ and the speed of the vessel (average 2.5 knots; Gunderson 1993; King 2007), and biomass of the Caribbean lobster was estimated in $\mathrm{kg} \mathrm{km}^{-2}$.

The total weight, sex and number of individuals per species from each station were recorded. All the specimens were weighed to the nearest $0.1 \mathrm{~g}$, and the carapace length (CL) was measured to the nearest $0.1 \mathrm{~mm}$ using callipers from the posterior edge of the eye socket to the middle hind margin of the carapace. The frequency data of CL by sex and by strata of depth of Metanephrops binghami were analysed as a mixture of probability density functions (pdf), whose modes depend upon a combination of the distances between means, the magnitudes of the variances, the proportion of the individual

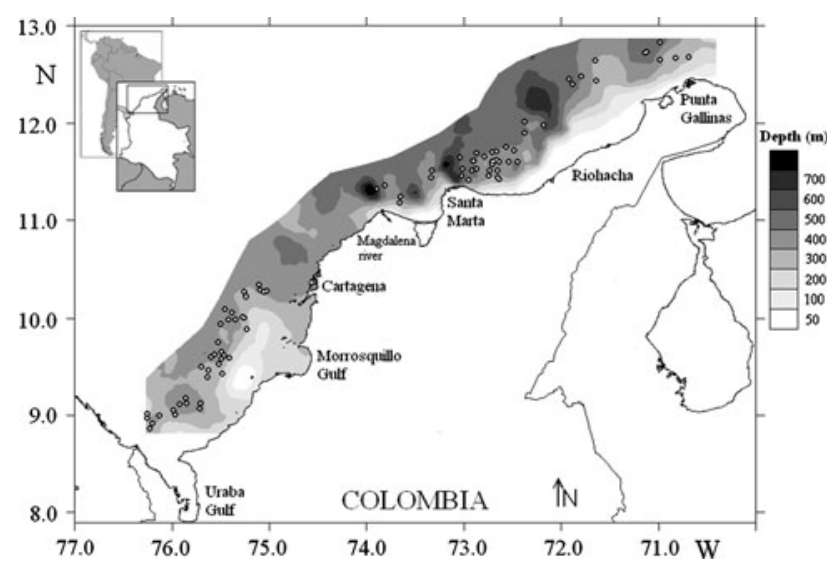

Fig. 1 Study area in the Colombian Caribbean Sea. Circles indicate the sampled stations numbers in each mode and the overall sample size. The quasiNewton algorithm was used to fit the frequency of data per individual to obtain the means, using the software MIX (Mixture analysis). The statistical method used to fit the mixture distribution to the data is maximum-likelihood estimation for grouped data (MacDonald and Pitcher 1979). Oneway ANOVA was used to test for significant differences between sexes of each measurement, once the assumptions of normality and homogeneity of variance were achieved following log-transformation of the data. We used the Student's $t$ test for differences between means of CL by depth strata for both females and males (Gotelli and Ellison 2004; Manly 2004). Ovary staging was based on the colour of the ovary (adapted from Mente et al. 2009): stage 1, white-immature; stage 2, opaque-in development; stage 3, yellow-maturing; stage 4 , green-mature; stage 5 , ovigerous female carrying eggs on its pleopods. For the estimation of the maturity at length, we considered stages I and II as immature and stages III, IV and $\mathrm{V}$ as mature. Size at sexual maturity $\left(\mathrm{l}_{50 \%}\right)$ was modelled by fitting the logistic function of a mature specimen proportion with $2 \mathrm{~mm}$ of size interval of CL. The curve was fitted by applying the maximum likelihood and uncertainty by Monte Carlo resampling (Manly 2006) to obtain the estimated parameters and the confidence intervals (C.I.; Roa et al. 1999).

$$
\mathrm{P}(\mathrm{l})=\frac{1}{1+\exp (a+b * \mathrm{CL})}
$$

where $\mathrm{P}(1)$ is the mature female proportion, $a$ and $b$ are the parameters estimated by resampling and CL the carapace length. The size at $50 \%$ maturity is $\mathrm{CL}_{50 \%}=-(a / b)$ (King 2007).

Geostatistical analyses (Cressie 1993; Petitgas 1993; Rivoirard et al. 2000) were used to describe the spatial structure of the Caribbean lobster distribution. The experimental variogram is defined as the variance of difference between values that are $h$ units apart.

$\hat{\gamma}(h)=\frac{1}{2 N(h)} \sum_{i=1}^{N(h)}\left[z\left(x_{i}\right)-z\left(x_{i}+h\right)\right]^{2}$

where $\hat{\gamma}(h)$ is semivariance, $h$ is a vector of distance and direction, and $N(h)$ is the number of pairs of observations at distance $h$ and given direction, $z\left(x_{i}\right)$ is the density of $M$. binghami for the $i$ th data point. In order to evaluate the anisotropic processes, experimental directional variograms were calculated for raw data $\left(0^{\circ}, 45^{\circ}, 90^{\circ}\right.$ and $\left.135^{\circ}\right)$. Finally, ordinary point kriging was used to map the spatial distribution, to estimate the mean density, the variance of the mean density and the biomass (Isaaks and Srivastava 1989; Petitgas and Prampart 1995; Rivoirard et al. 2000).

Generalized Additive Modelling (GAM; Hastie and Tibshirani 1990) was used to analyse the depth preferences and diel periodicity in abundance of M. Binghami. An 
additive model is an extension of linear models, but allows linear functions of predictors (depth and hour) to be replaced by smoothing functions (Agenbag et al. 2003):

$y=\alpha+\sum_{i=1}^{n} f_{i}\left(X_{i}\right)+\varepsilon$

where $y$ is the response, $X_{i}$ is the predictor, $\alpha$ is a constant and $\varepsilon$ is the error. The $f_{i}$ is estimated using smoothers. We used spline (s) smoothing with a Gaussian family to estimate the nonparametric functions. The probability level of the nonlinear contribution of the nonparametric terms was made with the significance value $(P)$ for judging the goodness of fit (Burnham and Anderson 2002).

\section{Results}

The size of M. binghami females ranged between 15.5 and $55.3 \mathrm{~mm} \mathrm{CL}$ (mean $33.6 \mathrm{~mm}, \pm 7.2$ ) and for males between 17.0 and $56.3 \mathrm{~mm} \mathrm{CL}$ (mean $34.8 \mathrm{~mm}$, \pm 8.9 ). Statistically significant differences between the sexes were not found (Fig. 2), revealing size homogeneity for both sexes $(P=0.12)$. The entire length frequency distribution

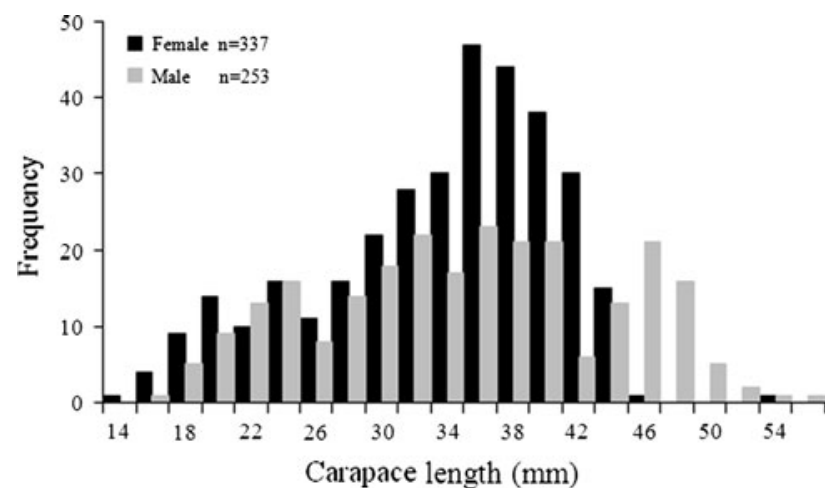

Fig. 2 Length frequency distributions of Metanephrops binghami of cephalothorax length (CL) of $M$. binghami $\mathrm{CL}$ was characterized by two modes for female and three for male (Table 1). For females, the first mode represented $20 \%$ (mean $22.3 \pm 4.4 \mathrm{~mm} \mathrm{CL}$ ) and the second one the $80 \%$ (mean $35.9 \pm 4.3 \mathrm{~mm} \mathrm{CL}$ ). For males, three modes were observed: the first (mean $20.8 \pm 2.2 \mathrm{~mm}$ CL) and third ( $45.9 \pm 1.4 \mathrm{~mm} \mathrm{CL})$ with $20 \%$ and the second represented $80 \%$ (mean $34.2 \pm 7.2 \mathrm{~mm} \mathrm{CL}$ ).

The size structure for the female $M$. binghami showed a small increase in CL associated with depth, with a two modal trend for all depth strata (Fig. 3; Table 1). The male M. binghami had three modal for the $200-300 \mathrm{~m}$ strata and one-modal structure for the $300-400 \mathrm{~m}$ strata, also an increasing CL with depth. The three modes of the males in the second strata seem to mix in the third strata. The largest numbers were found in the 200-300 and 300-400 m strata (Table 1). Low numbers of individuals caught in the strata 100-200 and 400-500 m prevented their inclusion in the test for significant differences of CL by depth strata. However, the mean CL of female and male of M. binghami did not differ significantly between $200-300$ and $300-400 \mathrm{~m}$ strata $(P=0.58)$.

Of the 336 females analysed to determine different maturity stages, $31.25 \%$ were immature and $68.75 \%$ mature. The size at $50 \%$ maturity $\left(l_{50 \%}\right)$ in females (Fig. 4) was $30.55 \mathrm{~mm} \mathrm{CL}$ (95\% C.I. lower $=30.53$, C.I. upper $=$ 30.58), the parameters $a=16.35$ (C.I. lower $=16.34$, C.I. upper $=16.50)$ and $b=-0.54$ (C.I. lower $=-0.54$, C.I. upper $=-0.54)$.

The unidirectional variograms showed similarities in their modelling of spatial characteristics for M. binghami (Fig. 5a). This absence of geometric anisotropy can be demonstrated with the ratio between the maximum and minimum values of the spatial autocorrelation range in the unidirectional variograms, which was less than 2 (Table 2). This means that the spatial structure of $M$. binghami aggregation has the same size in all directions of spatial autocorrelation. Therefore, the spatial structure of Caribbean lobster biomass $\left(\mathrm{kg} \mathrm{km}^{-2}\right)$ was studied using an

Table 1 Frequency distribution parameters (proportions of participation, means and standard deviations) for each mode of the histograms of CL of $M$. binghami by sex and strata

\begin{tabular}{|c|c|c|c|c|c|c|c|c|c|c|}
\hline \multirow[t]{2}{*}{ Strata $(m)$} & \multirow[t]{2}{*}{ Sex } & \multicolumn{3}{|c|}{ Proportions } & \multicolumn{3}{|c|}{ Means } & \multicolumn{3}{|c|}{ Standard deviations } \\
\hline & & pl & $p 2$ & p3 & $\mu 1$ & $\mu 2$ & $\mu 3$ & $\sigma 1$ & $\sigma 2$ & $\sigma 3$ \\
\hline All & $\mathrm{F}$ & 0.2 & 0.8 & - & 22.3 & 35.9 & - & 4.4 & 4.3 & - \\
\hline All & M & 0.1 & 0.8 & 0.1 & 20.8 & 34.2 & 45.9 & 2.2 & 7.2 & 1.4 \\
\hline $200-300$ & $\mathrm{~F}$ & 0.2 & 0.8 & - & 20.2 & 35.6 & - & 4.0 & 3.9 & - \\
\hline $300-400$ & $\mathrm{~F}$ & 0.6 & 0.4 & - & 28.1 & 38.0 & - & 6.3 & 3.1 & - \\
\hline $200-300$ & M & 0.2 & 0.6 & 0.2 & 20.9 & 33.0 & 46.3 & 3.2 & 4.8 & 2.0 \\
\hline $300-400$ & M & 1.0 & - & - & 33.9 & - & - & 8.5 & - & - \\
\hline
\end{tabular}

Mean and standard deviations are from normal pdf 
Fig. 3 Length frequency distribution of carapace length (CL) by sex and depth strata for M. binghami
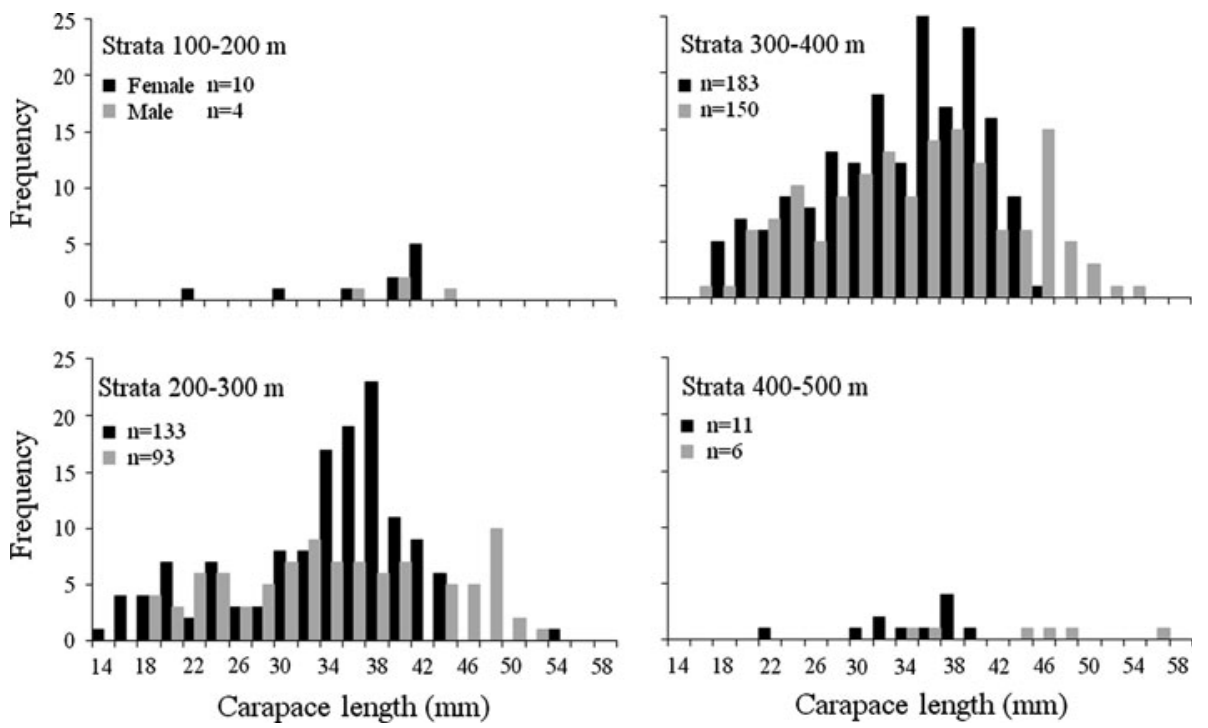

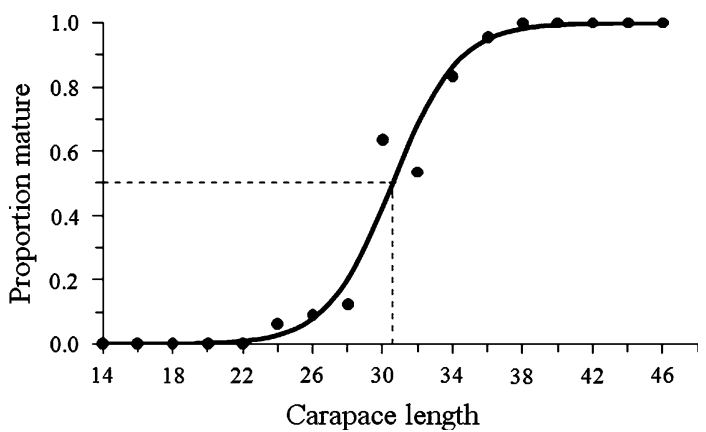

Fig. 4 Size at 50\% sexual maturity for females of $M$. binghami
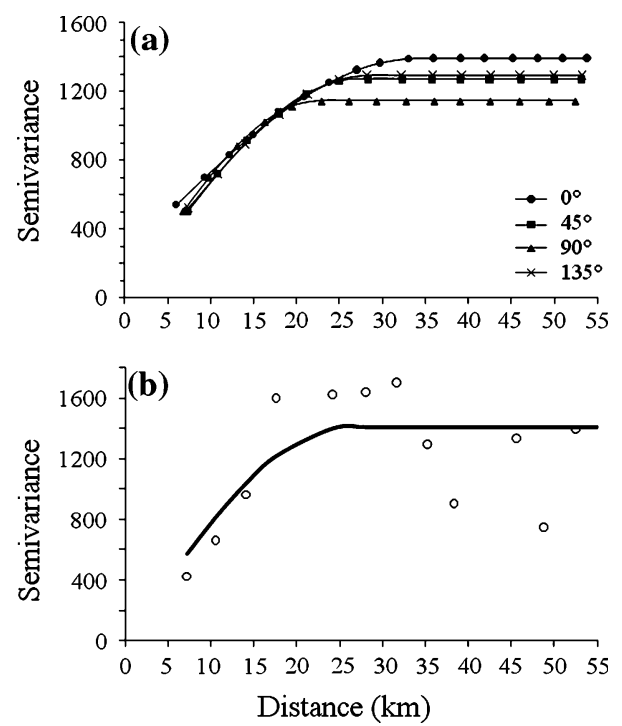

Fig. 5 Directional experimental (a) and omnidirectional (b) variograms showing an isotropic process in abundance of Metanephrops binghami in Colombian Caribbean Sea
Table 2 Analysis of anisotropy, spherical variogram model fitted to the directional empirical variogram and omnidirectional spherical model of variogram for Metanephrops binghami

\begin{tabular}{lrrrrr}
\hline Parameter & $0^{\circ}$ & \multicolumn{1}{c}{$45^{\circ}$} & $90^{\circ}$ & $135^{\circ}$ & Isotropic \\
\hline Nugget & 239.2 & 0.0 & 0.0 & 39.4 & 0.0 \\
Nugget (\% sill) & 17.1 & 0.0 & 0.0 & 3.0 & 0.0 \\
Sill & $1,156.3$ & $1,271.3$ & $1,146.0$ & $1,257.6$ & $1,410.9$ \\
Range & 34.0 & 27.0 & 22.6 & 28.5 & 25.7 \\
Ratio & 1.0 & 1.3 & 1.5 & 1.2 & - \\
\hline
\end{tabular}

experimental isotropic variogram (Fig. 5b). The fitted spherical variograms showed a nonresolved structure for the sampling design that considered $0.0 \%$ of total variance (nugget as percentage of sill; Table 2). The autocorrelation range of the Caribbean lobster was $25.7 \mathrm{~km}$, i.e. the diameter of $M$. binghami aggregation of high-density patches (Table 2). The higher biomass values were distributed in two well-defined spatial patches in the northern zone of the Colombian Caribbean Sea. The bulk of the biomass was distributed between Riohacha and off Punta Gallinas (mean density $=30.96 \mathrm{~kg} \mathrm{~km}^{-2}$; biomass $=445,945 \mathrm{~kg}$; CV $=$ 13.48). In the southern zone, this species revealed high abundances between Cartagena and off the Morrosquillo gulf (mean density $=20.40 \mathrm{~kg} \mathrm{~km}^{-2}$; biomass $=234,840 \mathrm{~kg}$; $\mathrm{CV}=20.46$; Fig. 6). The estimated mean density and biomass for the combined study area was $26.40 \mathrm{~kg} \mathrm{~km}^{-2}$ and $684,785 \mathrm{~kg}(\mathrm{CV}=15.81)$, respectively.

The nonlinear contribution of the nonparametric terms was significant $(P=0.00)$ in explaining the variability of depth preferences and diel periodicity in abundance of $M$. binghami. The relationship between the biomass of $M$. binghami and depth $\left(R^{2}=0.41\right)$ shows that this species was distributed between 110 and $440 \mathrm{~m}$, but higher biomass was found between 250 and $350 \mathrm{~m}$ (Fig. 7). 


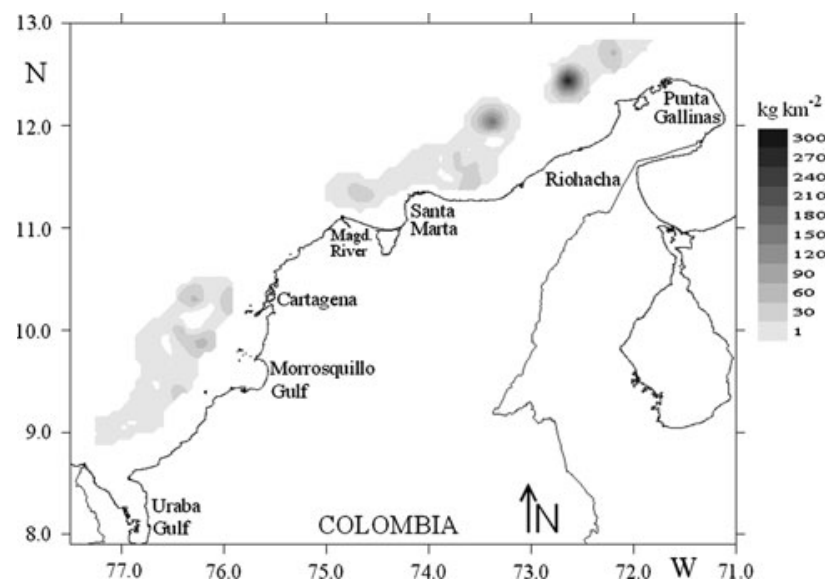

Fig. 6 Spatial distribution of Metanephrops binghami abundances $\left(\mathrm{kg} \mathrm{km}^{-2}\right)$ as the reproduction of a spatially stochastic process by kriging

$M$. binghami showed a marked diel pattern in the catches $\left(R^{2}=0.28\right)$, with high values of biomass found in the nocturne trawls, increasing after 18:00 with highest values from 0:00 to 4:00 and lowest values during daylight hours.

\section{Discussion}

The Colombian Caribbean Sea is influenced by the northeast trade winds, causing the surface currents flowing in west and south-west directions almost parallel to the coast. These trade winds are responsible of upwelling in the northern zone of the study area, which increases the productivity in the Guajira coast (Andrade et al. 2003; Paramo et al. 2003, 2009). In fact, the highest biomass of M. binghami was found in the northern zone of the Colombian Caribbean Sea, where the local oceanography is modulated by the seasonal upwelling with high productivity (Paramo et al. 2003, 2009). Studying the spatial distribution of populations is of great importance for ecological studies, because in the nature most of marine organisms are not distributed at random, rather, they are forming patches, gradients or other types of spatial structures (Rivoirard et al. 2000; Legendre and Fortin 1989;
Legendre 1993; Legendre and Legendre 1998; Paramo and Roa 2003). Also, successful fisheries management in new fisheries require the knowledge of population abundance, the spatial distribution, and size structure (Rivoirard et al. 2000), since failure to recognize spatial complexity of fisheries has resulted in stock collapses (Hilborn and Walters 2003; Katsanevakis and Maravelias 2009). Additionally, deep-sea crustaceans have a patchy distribution (D’Onghia et al. 1998; Maynou et al. 1998; Belcari et al. 2003), which justifies the importance of using geostatistics methods to address the spatial distribution structure and calculate the biomass more precisely (Paramo and Roa 2003).

Metanephrops binghami is found between 230 and $700 \mathrm{~m}$, although is most abundant between 300 and $500 \mathrm{~m}$ in the sand and mud bottoms (Tavares 2002); however, our results show higher biomass and size are found between 250 and $350 \mathrm{~m}$, with a maximum at about $300 \mathrm{~m}$, which suggests that this species prefers a narrow depth strata. The biomass obtained in this study $\left(26.40 \mathrm{~kg} \mathrm{~km}^{-2}\right)$ was higher than similar Nephopidae species (Nephrops norvegicus) on the Catalan Sea (18.87 $\mathrm{kg} \mathrm{km}^{-2}$; Maynou et al. 1998), which gives support to the proposed development of a new fishery in the Colombian Caribbean Sea. The higher biomass of $M$. binghami in the Colombian Caribbean Sea by depth strata is according to high aggregations of $M$. boschmai (250-350 m) in Australian waters, but M. andamanicus (350-400 m) and M. australiensis (430-470 m) were more deeper (Ward and Davis 1987). However, the Norway lobster (N. norvegicus) is distributed between 200 and $500 \mathrm{~m}$ (Maynou et al. 1998; Abelló et al. 2002), but the highest yields take place at the $500 \mathrm{~m}$ stratum (Fonseca et al. 2007). The size of M. binghami in this study is similar to other Nephropidae species (Nephrops norvegicus) caught in Portuguese waters, ranging from 18 to $59 \mathrm{~mm} \mathrm{CL}$ (Fonseca et al. 2007) and in the Catalan Sea (Spain, northwest Mediterranean), ranging from 12 to $58 \mathrm{~mm} \mathrm{CL}$ (Maynou et al. 1998), but smaller than reported of Nephrops andamicus in South Africa, ranging from 47 to $55 \mathrm{~mm}$ CL (Berry 1969). Moreover, the fecundity for females of $M$. binghami in Venezuela range between 102 and 781 eggs (mean 326) in the size range of $29-52 \mathrm{~mm}$
Fig. 7 Modelling of functional relationships between biomass with depth preferences and diel periodicity in catches
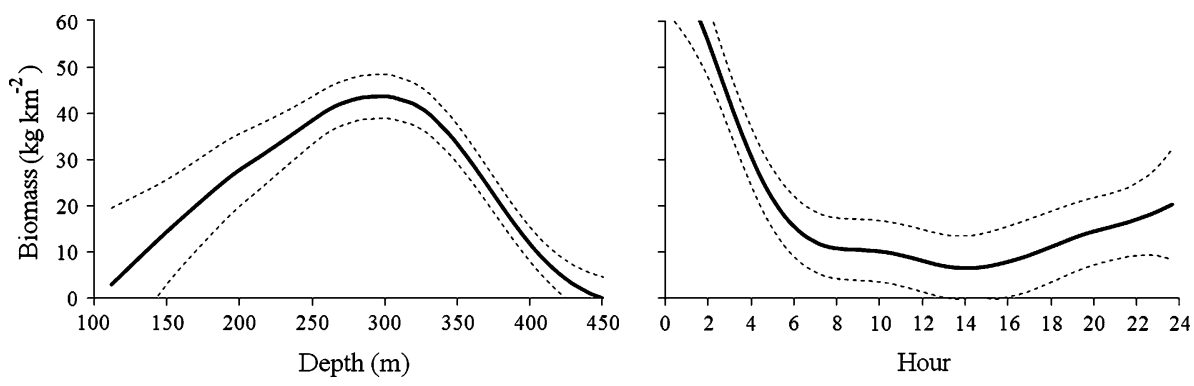
CL (Gómez et al. 2000, 2005), which agree with our results (30.55 mm CL for females) in the Colombian Caribbean Sea. The great proportions of large-sized individuals of $M$. binghami in our study reflect the unexploited populations in the study area.

Lobsters are described as nocturnal (Golet et al. 2006), remaining in shelters during daylight hours, which allows for protection from predators, and emerging from their burrows in the evening. Indeed, it is known that species of genus Metanephrops live in borrows (Tavares 2002). Ward and Davis (1987) showed that deep water benthic crustaceans have a marked diel periodicity with higher abundances of Metanephrops australiensis in nocturnal catches. The Norway lobster (Nephrops norvegicus) shows diel activity patterns at dawn and dusk when it leaves the burrows; the catches were higher at these times and were conversely sparse during the day (Trenkel et al. 2008). Aguzzi and Bahamon (2009) describe this behavioural rhythm as endobenthic, in which burrowers and buries show phases of emergence from the substrate and retraction in it. The animals rest when light increases and feed at darkness (Aguzzi and Company 2010). These patterns of diel periodicity agree with our results for $M$. binghami which also showed a nocturnal behaviour most likely for feeding and a burying behaviour during daylight, as the largest catches were taken during nocturnal trawls. This study is the first to provide evidence of diel patterns for $M$. binghami. Therefore, fishers can adapt their fishing strategy to the diel behaviour of this species. Holthuis (1991) reported on the big size and potential commercial importance of the species Metanephros. Nevertheless, according to our results, more scientific biological research is needed to understand the life cycle parameters of $M$. binghami, such as growth, reproduction size, recruitment, mortality, areas and season of spawning, nursery areas, and associate biodiversity before the initiation of a new commercial fishery. This information will aid in developing appropriate strategies to initiate, manage and sustain a new commercial fishery, while taking into account protection and conservation of the existing ecosystem.

Acknowledgments This work is a contribution of the LeibnizZentrum für Marine Tropenökologie (ZMT), Germany and Research group Ciencia y Tecnología Pesquera Tropical (CITEPT) Universidad del Magdalena (Colombia). Writing of the manuscript was supported by the ALECOL-DAAD Ph.D. Scholarship, Universität Bremen, Germany. We thank Dr. Marc Taylor (AWI - Alfred Wegener Institut für Polar und Meeresforschung) and Dr. Alejandro Espinoza (ZMT) for helpful and insightful comments on the manuscript. Two anonymous referees provided helpful comments on the manuscript. We also thank the crew of vessel "Tee Claude" and Captain José Guillem and members of research group CITEPT that participated in the laboratory and research surveys. The work was sponsored by COLCIENCIAS grant number 117-452-21288, Universidad del Magdalena and the Instituto Colombiano de Desarrollo Rural (INCODER) through Subgerencia de Pesca y Acuicultura.

\section{References}

Abelló P, Abella A, Adamidou A, Jukic-Peladic S, Maiorano P, Spedicato MT (2002) Geographical patterns in abundance and population structure of Nephrops norvegicus and Parapenaeus longirostris (Crustacea: Decapoda) along the European Mediterranean coasts. Sci Mar 66(2):125-141

Agenbag JJ, Richardson AJ, Demarcq H, Fréon P, Weeks S, Shillington FA (2003) Estimating environmental preferences of South African pelagic fish species using catch size and remote sensing data. Prog Ocean 59:275-300

Aguzzi J, Bahamon N (2009) Modelled day-night biases in decapods assessment by bottom trawling survey. Fish Res 100:274-280

Aguzzi J, Company JB (2010) Chronobiology of deep water continental margin decapods. Adv Mar Biol 58:155-225

Andrade CA, Barton ED, Mooers CHNK (2003) Evidence for an eastward flow along the Central and South American Caribbean Coast. J Geoph Res 108:1-11

Belcari P, Viva C, Mori M, de Ranieri S (2003) Fishery and biology of Aristaeomorpha foliacea (Risso, 1827) (Crustacea: Decapoda) in the Northern Tyrrenian Sea (western Mediterranean). J Northw Atlant Fish Sci 31:195-204

Berry PF (1969) The biology of Nephrops andamicus Wood-Mason (Decapoda, Reptantia). Investigational Report No. 22. Oceanographic Research Institute, Durban

Burnham KP, Anderson DR (2002) Model selection and multimodel inference: a practical information-theoretic approach. SpringerVerlag, New York

Chan TY (1998) Shrimps and prawns. In: Carpenter KE, Niem VH (eds) Species identification guide for fisheries purposes. The living marine resources of the Western Central Pacific. FAO, Rome, pp 851-971

Chan TY, Yu HP (1987) Metanephrops formosanus sp. Nov., a new species of lobster (Decapoda, Nephropidae) from Taiwan. Crustaceana 52(2):172-186

Chan TY, Ho KC, Li CP, Chu KH (2009) Origin and diversification of clawed lobster genus Metanephrops (Crustacea: Decapoda: Nephropidae). Mol Phyl Evol 50:411-422

Choi JH, Kim JN, Kim MH, Chang DS, Yoo JT, Kim JK (2008) Population biology and feeding habitats of the nephropid lobster Metanephrops thomsoni (Bate 1888) in the East China Sea. J Env Biol 29(4):453-456

Cressie NAC (1993) Statistics for spatial data. Wiley, New York

D’Onghia G, Tursi A, Maiorano P, Panza M (1998) Distribution, biology, and population dynamics of Aristaeomorpha foliacea (Risso, 1827) (Decapoda, Natantia, Aristeidae) in the north-western Ionian Sea (Mediterranean Sea). Crustaceana 71:518-544

Fonseca P, Campos A, Millar RB (2007) Codend selection in the deep-water crustacean trawl fishery in Portuguese southern waters. Fish Res 85:49-60

Golet WJ, Scopel DA, Cooper AB, Watsin WH III (2006) Daily patterns of locomotion expressed by American lobsters (Homarus americanus) in their natural habitat. J Crust Biol 26(4): $610-620$

Gómez G, Guzmán R, Marcano L (2000) Contribución al conocimiento de la Cigala del Caribe, Metanephrops binghami, en aguas de Venezuela: aspectos biométricos y fecundidad. Zoo Trop 18(1):107-118

Gómez G, Marcano L, Guzmán R, Ramírez T (2005) Aspectos biométricos y reproductivos de la Cigala, Metanephrops binghami, en aguas de Venezuela. Proc Gulf Car Fish Inst 47:537-547

Gotelli NJ, Ellison AM (2004) A primer of ecological statistics. Sinauer Associates, Massachusetts

Gunderson DR (1993) Surveys of fisheries resources. Wiley, New York 
Hastie TJ, Tibshirani RJ (1990) Generalized additive models. Chapman and Hall, London

Hilborn R, Walters C (2003) Quantitative fisheries stock assessment: choice, dynamics and uncertainty. Springer, London

Holthuis LB (1991) Marine lobsters of the world. FAO species catalogue vol 13. FAO Fisheries Synopsis

Isaaks EH, Srivastava RM (1989) Applied geostatistics. Oxford University Press, New York

Katsanevakis S, Maravelias CD (2009) Bathymetric distribution of demersal fish in the Aegean and Ionian Seas based on generalized additive modelling. Fish Sci 75:13-23

King M (2007) Fisheries biology, assessment and management. Blackwell publishing, Oxford

Legendre P (1993) Spatial autocorrelation: trouble or new paradigm? Ecology 74(6):1659-1673

Legendre P, Fortin MJ (1989) Spatial pattern and ecological analysis. Vegetatio 80:107-138

Legendre P, Legendre L (1998) Numerical ecology. Elsevier Science, Amsterdam

Macdonald PD, Pitcher TJ (1979) Age-groups from size-frequency data: a versatile and efficient method of analyzing distribution mixtures. J Fish Res Board Can 36:987-1001

Manly BFJ (2004) Multivariate statistical methods: a primer. Chapman and Hall/CRC, New York

Manly BFJ (2006) Randomization, bootstrap and Monte Carlo methods in biology. Chapman and Hall, New York

Maynou FX, Sardá F, Conan GY (1998) Assessment of the spatial structure and biomass of Nephrops norvegicus (L) populations in the north-western Mediterranean by geostatistics. ICES J Mar Sci 55:102-120

Mente E, Karapanagiotidis IT, Logothetis P, Vafidis D, Malandrakis E, Neofitou N, Exadactylos A, Stratakos A (2009) The reproductive cycle of Norway lobster. J Zool 278:324-332

Paramo J, Roa R (2003) Acoustic-geostatistical assessment and habitat-abundance relations of small pelagic fish from the Colombian Caribbean. Fish Res 60:309-319

Paramo J, Quiñones RA, Ramirez A, Wiff R (2003) Relationship between abundance of small pelagic fishes and environmental factors in the Colombian Caribbean Sea: an analysis based on hydroacustic information. Aquat Liv Res 16(3):239-245

Paramo J, Guillot L, Benavides S, Rodríguez A, Sánchez C (2009) Aspectos poblacionales y ecológicos de peces demersales de la zona norte del Caribe colombiano en relación con el hábitat: una herramienta para identificar Áreas Marinas Protegidas (AMPs) para el manejo pesquero. Caldasia 31(1):123-144

Petitgas P (1993) Geostatistics for fish stock assessments: a review and an acoustic application. ICES J Mar Sci 50:285-298

Petitgas P, Prampart A (1995) EVA: estimation variance: a geostatistical software for structure characterization and variance computation. Editions Orstom. logOrstom, Paris

Rivoirard J, Simmonds J, Foote KG, Fernandes P, Bez N (2000) Geostatistics for estimating fish abundance. Blackwell Science, London

Roa R, Enst B, Tapia F (1999) Estimation of size at sexual maturity: an evaluation of analytical and resampling procedures. Fish Bull 97:570-580

Smith PJ (1999) Allozyme variation in scampi (Metanephrops challenger) fisheries around New Zealand. N Zea J Mar Fresh Res 33:491-497

Tavares M (2002) Shrimps. In: Carpenter KE (ed) The living marine resources of the western central Atlantic, species identification guide for fisheries purposes. FAO, Rome, pp 251-291

Trenkel VM, Rochet MJ, Mahévas S (2008) Interactions between fishing strategies of nephrops trawlers in the Bay of Biscay and Norway lobster diel activity patterns. Fish Man Ecol 15(1):11-18

Tshudy D, Chan TY, Sorhannus U (2007) Morphology based cladistic analysis of Metanephrops: the most diverse extant genus of clawed lobster (Nephropidae). J Crust Biol 27(3):463-476

Ward TJ, Davis TLO (1987) Diel periodicity of Metanephrops australiensis and other deep-water Crustaceans of northwest Australia. Fish Res 5:91-97

Wassenberg TJ, Hill BJ (1989) Diets of four decapod crustaceans (Linuparus trigonus, Metanephrops andamanicus, M. australiensis and $M$. boschmai) from the continental shelf around Australia. Mar Biol 103:161-167 